\title{
EVALUASI ATAS TRANSFER DANA OTONOMI KHUSUS DI ACEH, PAPUA, DAN PAPUA BARAT
}

\author{
Hasta Budiratna dan Riatu M. Qibthiyyah \\ Universitas Indonesia \\ Email: Hastabudiratna08@gmail.com,prcrmqx@ gmail.com
}

\begin{tabular}{ll}
\hline \multicolumn{2}{c}{ Artikel info } \\
\hline Artikel history \\
$\begin{array}{ll}\text { Diterima } & : 29-11-2020 \\
\text { Direvisi } & : 06-12-2020 \\
\text { Disetujui } & : 17-12-2020\end{array}$
\end{tabular}

Kata kunci: Desentralisasi Asimetris, Dana Otonomi Khusus (Otsus), Angka Kemiskinan, dan Angka Partisipasi Murni (APM)

Keywords: Asymmetric Decentralization, Special Autonomy Fund (Otsus), Poverty Rate, and Pure Participation Rate (APM).

\begin{abstract}
Abstrak
Indonesia telah menerapkan kebijakan desentralisasi, tidak saja yang berlaku umum untuk seluruh wilayah di Indonesia, tapi juga sudah mengadopsi desentralisasi asimetris utamanya untuk wilayah-wilayah tertentu seperti Aceh, Papua, dan Papua Barat. Kebijakan desentralisasi asimetris ini, melimpahkan kewenangan yang lebih besar untuk fungsi tertentu kepada wilayah terkait, yang juga didukung melalui alokasi dana transfer Otonomi Khusus dari pemerintah pusat. Transfer Dana Otonomi Khusus ini telah berjalan belasan tahun dan akan segera berakhir pada 2022 (untuk Papua dan Papua Barat) dan 2028 (untuk Aceh). Transfer Dana Otonomi Khusus diantaranya digunakan untuk membiayai programprogram pengentasan kemiskinan dan pendidikan. Kedua hal tersebut merupakan dua indikator penting dalam capaian pembangunan daerah, terutama dikaitkan dengan kondisi capaian pembangunan yang relatif belum baik apabila dibandingkang daerah lain di Indonesia. Angka kemiskinan, secara rata-rata untuk periode 2015-2018, di ketiga daerah tersebut masih berada di atas rata-rata nasional, termasuk juga untuk partisipasi pendidikan khususnya di Papua dan Papua Barat. Oleh sebab itu, studi ini bertujuan untuk mengetahui besaran pengaruh Dana Otonomi Khusus terhadap angka kemiskinan dan Angka Partisipasi Murni jenjang pendidikan SMP di Aceh, Papua, dan Papua Barat. Menggunakan regresi data panel, studi ini mencakup 23 kabupaten/kota di Aceh dan

11 kabupaten/kota di Papua Barat pada tahun 2013-2018. Sedangkan Papua dilakukan pada 29 kabupaten/kota tahun 2015-2018. Hasil penelitan ini menunjukkan bahwa Dana Otonomi Khusus pada kabupaten/kota di Papua Barat secara signifikan berkorelasi dengan penurunan angka kemiskinan, dan peningkatan angka Partisipasi Murni jenjang SMP, namun studi ini belum menemukan korelasi yang cukup kuat untuk konteks Dana Otonomi Khusus yang diterima kabupaten/kota di Papua dan Aceh.
\end{abstract}

\footnotetext{
Abstract

Indonesia has implemented a decentralization policy, not only that is generally applicable to all regions in Indonesia, but has also adopted asymmetric decentralization, especially for certain areas such as Aceh, Papua and West Papua. This asymmetric decentralization policy, delegates greater authority for certain functions to the related regions, which is also supported through the allocation of Special Autonomy transfer funds from the central government. The transfer of the Special Autonomy Fund has been going on for a dozen years and will end soon in 2022 (for Papua and West Papua) and 2028 (for Aceh). Transfers of the Special Autonomy Fund, among others, are used to finance poverty alleviation and education programs. These two things are two important indicators in the achievement of regional development, especially in relation to the relatively poor condition of development achievements compared to other regions in Indonesia. The poverty rate, on average for the 2015-2018 period, in the three regions is still above the national average, including also for education participation, especially in Papua and West Papua. Therefore, this study aims to determine the magnitude of the influence of the Special Autonomy Fund on the poverty rate and the Pure Enrollment Rate for junior high school education in Aceh, Papua and West Papua. Using panel data regression, the study covered 23 districts / cities in Aceh and 11 districts / cities in West Papua in 2013-2018. Meanwhile, Papua was conducted in 29 districts / cities in 2015-2018. The results of this study indicate that the Special Autonomy Fund in districts / cities in West Papua is significantly correlated with a reduction in poverty and an increase in junior high school enrollment rates, but
} 
this study has not found a strong enough correlation in the context of the Special Autonomy Funds received by districts in Papua and Aceh.

Koresponden author: Hasta Budiratna

Email: Hastabudiratna08@gmail.com artikel dengan akses terbuka dibawah lisensi

CC BY SA

2020

\section{Pendahuluan}

Indonesia telah menerapkan kebijakan desentralisasi, tidak saja yang berlaku umum untuk seluruh wilayah di Indonesia, tapi juga sudah mengadopsi desentralisasi asimetris, utamanya untuk wilayah-wilayah tertentu. Kebijakan desentralisasi asimetris ini, melimpahkan kewenangan yang lebih besar untuk fungsi tertentu kepada wilayah terkait,yang juga didukung melalui alokasi dana transfer dari pemerintah pusat.

Tantangan transfer asimetris adalah bahwa manfaat dari dana transfer ini benar-benar sampai ke populasi yang membutuhkan, mengingat baik Aceh, Papua, dan Papua Barat tidak memiliki Pendapatan Asli Daerah (PAD) atau kualitas layanan publik yang relatif tinggi daripada provinsi lain di Indonesia (Agustina et al., 2012). Oleh karena itu diperlukan pembangunan social yang merupakan sebuah proses perencanaan perubahan sosial yang 
dirancang untuk kesejahteraan masyarakat. Hakikat transfer asimetris melalui Otonomi Khusus bagi Aceh, Papua Barat dan Papua adalah sejauh mana pembangunan dapat meningkatkan kualitas hidup untuk meningkatkan kesejahteraan masyarakat melalui penyelesaian konflik, rehabilitasi, dan rekonstruksi pasca konflik. Kondisi ini diharapkan dapat meningkatkan partisipasi pendidikan, meningkatan pendapatan per kapita, dan mengurangi angka kemiskinan. Salah satu contoh kebijakan desentralisasi asimetris di Indonesia, yang diadopsi sejak tahun 2001 yang menandai era "big-bang decentralization", adalah kebijakan otonomi khusus untuk wilayah Aceh, Papua, yang dilanjutkan dengan Papua Barat. Terkait dengan pemberian otonomi khusus di ketiga wilayah ini, adalah salah satu bentuk untuk meredakan konflik yang terjadi di wilayah tersebut (Dardias, 2012).

Konstitusi pemerintah Republik Indonesia sebetulnya telah cukup responsif mengakomodir tuntutan beberapa daerah khususnya terkait keadilan fiskal antara pemerintah pusat dan daerah. Undang- Undang Dasar 1945 pasal 18 B menempatkan beberapa provinsi di Indonesia sebagai daerah khusus atau istimewa. Ayat (1) pasal terebut menyatakan bahwa Negara mengakui dan menghormati satuan-satuan pemerintah daerah yang bersifat khususatau bersifat istimewa yang diatur dengan undang- undang. Atas dasar UUD 45, desentralisasi asimetris memperoleh ruangnya di Republik Indonesia dengan menitikberatkan pada kekhususan, keistimewaan dan keberagaman daerah yang selanjutnya diatur lebih lanjut dengan Undang-Undang.

Menurut (Tauda, 2018), desentralisasi asimetris (asymmetrical decentralisation) merupakan pemberlakuan kewenangan khusus yang hanya diberikan kepada daerah-daerah tertentu pada suatu negara sebagai alternatif penyelesaian permasalahan hubungan antara pemerintah pusat dan daerah dalam konteks ini untuk menjaga kesatuan daerah dalam kerangka NKRI. Desentralisasi asimetris mencakup desentralisasi politik, ekonomi, fiskal dengan mempertimbangkan kekhususan dan keistimewaannya yang tidak berlaku seragam di semua daerah. Daerah dengan desentralisasi asimetris di Indonesia adalah Papua, PapuaBarat, Aceh, DKI Jakarta, dan Daerah Istimewa Yogyakarta. Kelima provinsi tersebut telah memiliki UU tersendiri yang mengatur kekhususan dan keistimewaan yang dimiliki. Desentralisasi asimetris menjadikan kelima daerah tersebut memiliki ruang gerak yang lebih terbuka dalam pelaksanaan pemerintahan daerah di luar ketentuan yang diatur pada Undang- Undang Nomor 23 Tahun 2014 tentang Pemerintahan Daerah.

Desentralisasi asimetris merupakan kontra konsep dari desentralisasi simetris (symmetrical decentralisation) yang berlaku pada 29 provinsi di Indonesia. Sementara itu, (Tauda, 2018) menyatakan bahwa desentralisasi simetris merupakan perwujudan desentralisasi yang seragam yang mengacu pada Undang-Undang tentang Pemerintahan Daerah Nomor 23 Tahun 2014 - menekankan pada pelimpahan kewenangan yang menjadi urusan daerah kepada seluruh daerah di Indonesia secara serempak. Kedua konsep baik desentralisasi simetris maupun asimetris dijalankan secara bersamaan dalam praktek ketatanegaraan di Republik Indonesia.

Berdasar ketentuan Undang- Undang, bahwa Dana Otonomi Khusus di Aceh, Papua, dan Papua Barat hanya diberikan pemerintah pusat selama 20 tahun. Hal ini menjadikan Aceh akan kehilangan Dana Otsus pada tahun 2028, sementara Papua dan Papua Barat pada tahun 2022. Sektor pendidikan dan kesejahteraan sosial akan menjadi sektor terdampak dengan berhentinya penerimaan anggaran yang berasal dari kontribusi Dana Otonomi 
Khusus. Selain berkurangnya penerimaan daerah yang berasal dari Dana Otonomi Khusus, Papua dan Papua Barat juga akan memperoleh pengurangan persentase Dana Bagi Hasil Migas menjadi hanya $50 \%$ pada 2027 dari $70 \%$ pada tahun 2002 sd 2026. Pada saat itu, tentu saja diharapkan peran Pendapatan Asli Daerah telah mampu menggantikan proporsi dana otonomi khusus bagi pembiayaan sektor-sektor publik khususnya pendidikan dan kesejahteraan sosial di Papua dan Papua Barat.

Tabel 1. Realisasi Penerimaan Dana Otsus, PAD di Aceh, Papua, dan Papua Barat Tahun 2018

\begin{tabular}{|l|c|c|r|}
\hline $\begin{array}{l}\text { PROVINSI } \\
\text { INDIKATOR }\end{array}$ & $\begin{array}{c}\text { DANAOTS } \\
\text { US(RP) }\end{array}$ & PAD(Rp) & Daper(Rp) \\
\hline ACEH & 5.973 .040 .45 & 2.786 .413 .382 .000 & 17.329 .971 .518 .00 \\
& 9.000 & & 0 \\
\hline PAPUABARAT & 3.772 .808 .09 & 477.620 .965 .000 & 9.858 .075 .272 .000 \\
& 3.000 & & 28.158 .591 .932 .00 \\
\hline PAPUA & 9.433 .346 .93 & 1.349 .793 .880 .000 & 0 \\
\hline
\end{tabular}

*Sumber; Statistik Keuangan Kabupaten Kota BPS, 2019 Angka merupakan agregat dari kabupaten kota

Komposisi penerimaan daerah kabupaten/kota di Aceh, Papua, dan Papua Barat secara umum adalah berasal dari Pendapatan Asli Daerah (PAD), Dana Perimbangan (Dana Bagi Hasil Pajak, Bagi Hasil SDA, DAU, DAK), dan Dana Otonomi Khusus (Otsus). Data Badan Pusat Statistik (BPS) untuk kabupaten/kota di Aceh, Papua, dan Papua Barat tahun 2018 pada tabel di atas menunjukkan bahwa secara umum Dana Perimbangan merupakan komponen terbesar penerimaan ketiga provinsi tersebut disusul dengan Dana Otonomi Khusus dan Pendapatan Asli Daerah (PAD). Papua merupakan daerah yang menerima transfer pusat terbesar melalui Dana Perimbangan dan Dana Otsus. Namun demikian, komponen penerimaan yang berasal dari internal daerah yakni PAD adalah yang terendah dibanding komponen penerimaan lainnya. Aceh, dan Papua Barat juga hanya mampu menghasilkan PAD yang tergolong kecil dibanding proporsi dana transfer pusat. Sementara, Dana Otsus pada akan segera berakhir pada 2022 untuk Papua dan Papua Barat dan 2028 untuk Aceh.

Studi ini membatasi lokus penelitian pada desentralisasi asimetris kabupaten/kota di Aceh, Papua, dan Papua Barat-mengingat kesamaan latar belakang konflik separatis di ketiga daerah tersebut. Selain itu penulis tertarik dengan ketiga daerah tersebut mengingat capaian pembangunan khususnya sektor pendidikan (Angka Partisipasi Murni) di Papua dan Papua Barat masih berada di bawah rata-rata nasional. Dalam pengentasan kemiskinan (Angka Kemiskinan) di Aceh, Papua, dan Papua Barat juga masih berada di atas angka rata-rata nasional. Hingga 18 tahun pasca diberlakukan desentralisasi asimetris, Papua masih konsisten menjadi provinsi dengan APM dan Angka Kemiskinan terburuk di Indonesia. Terkecuali Aceh, Papua dan Papua Barat juga masih menghadapi konflik separatisme yang menelan banyak korban jiwa hingga saat ini. Mengingat hal ini, penulis tertarik untuk mengetahui pengaruh Dana Otonomi Khusus terhadap Angka Partisipasi Murni (APM) pendidikan dasar SMP dan Angka Kemiskinan kabupaten/kota di Aceh, Papua, dan Papua Barat. 


\section{Metode Penelitian}

\section{Jenis dan Sumber Data}

Jenis data yang digunakan dalam penelitian ini adalah data sekunder yang bersumber dari Badan Pusat Statistik, Direktorat Jenderal Perimbangan Keuangan Kementerian Keuangan, dan Kementerian Pendidikan dan Kebudayaan. Penelitian ini dilakukan terhadap kabupaten/kota di Aceh (23 kabupaten/kota) dan dan Papua Barat (11 kabupaten/kota) pada 2013-2018. Sedangkan kabupaten/kota di Papua (29 kabupaten/kota) dilakukan pada 20152018.

\section{Metode Analisis}

Analisis inferensial digunakan untuk melihat pengaruh pemberian Dana Otonomi Khusus terhadap angka kemiskinan dan partisipasi pendidikan. Metode analisis inferensial yang digunakan adalah dengan analisis data panel. Studi ini menggunakan analisis regresi linear berganda karena peneliti hendak mengetahui besaran pengaruh beberapa variabel independent Dana Otonomi Khusus (Otsus), Pendapatan Asli Daerah (PAD), Dana Perimbangan (DP), Realisasi Belanja Fungasi Pendidikan (RBP), Realisasi Belanja Fungsi Perlindungan Sosial (RBPS), PDRB per Kapita (PDRBK), dan populasi (Pop) terhadap variabel dependent Angka Kemiskinan (Pov) dan Angka Partisipasi Murni (APM) jenjang Pendidikan dasar SMP di Aceh, Papua Barat dan Papua. Hal ini bertujuan untuk membuat prediksi nilai variabel dependent apabila nilai variabel independent yang berhubungan dengannya sudah ditentukan. Selain itu untuk menguji signifikansi pengaruh variabel independent terhadap variabel dependent. Variabel- variabel yang digunakan mengacu pada penelitian-penelitian sebelumnya tentang Dana Otsus di Aceh dan Papua oleh (Hartati et al., 2016), (Astuti \& Astika, 2016), (Monika, 2018), dan (Rasu et al., 2019)

Fungsi persamaan umum dalam penelitian ini adalah:

$\mathrm{APM}_{\mathrm{it}}=\beta_{\mathrm{o}}+\beta 1 \ln (\text { Otsus })_{\mathrm{it}}+\beta 2 \ln (\mathrm{PAD})_{\text {it }}$

$+\beta 3 \ln (\mathrm{DP})_{i \mathrm{it}}+\beta 4 \ln (\mathrm{PDRBK})_{i t}+\beta 5 \ln (\mathrm{RBP})_{i t}+\beta 6 \ln (\mathrm{Pop})_{i t}+\mathrm{e}_{\mathrm{it}}$

$\operatorname{Pov}_{\text {it }}=\beta o+\beta 1 \ln (\text { Otsus })_{\text {it }}+\beta 2 \ln (\mathrm{PAD})_{\text {it }}$

$+\beta 3 \ln (\mathrm{DP})_{\text {it }}+\beta 4 \ln (\mathrm{PDRBK})_{\text {it }}+\beta 5 \ln (\mathrm{RBPS})$ it $+\beta 6 \ln (\mathrm{Pop})$ it + eit

\section{Keterangan :}

APM : Angka Partisipasi Murni jenjang SMP kabupaten ke i periode ke t

Pov : Angka Kemiskinan kabupaten ke i periode ke $\mathrm{t}$

Otsus : Dana Otsus kabupaten ke i periode ke $\mathrm{t}$

PAD : Pendapatan Asli Daerah kabupaten ke i periode ke $t$

DP : Dana Perimbangan kabupaten ke i periode ke $t$

PDRBK: PDRB per kapita kabupaten ke i periode ke $\mathrm{t}$

Pop : Jumlah Penduduk kabupaten i periode ke $\mathrm{t}$

E : kesalahan karena faktor acak kabupaten ke i periode ke $\mathrm{t}$

$\beta 1, \beta 2 \ldots$ : koefisien regresi sekaligus koefisien elastisitas 


\section{Hasil dan Pembahasan}

\section{Perbandingan Angka Kemiskinan dan Angka Partisipasi Murni SMP di Aceh, Papua, dan Papua Barat}

Secara umum, ketiga provinsi dengan desentralisasi asimetris tersebut masih memiliki tingkat kemiskinan yang masih berada di bawah rata-rata nasional. Papua merupakan provinsi dengan angka kemiskinan tertinggi dan APM terendah diantara provinsilainnya. Namun demikian secara tren Angka Partisipasi Murni SMP di Papua memperlihatkan peningkatan dari tahun-tahun. Angka kemiskinan Papua juga memperlihatkan penurunan dalam 3 tahun terakhir (2016- 2018) meskipun sangat landai(laju penurunan sangat kecil). Aceh menjadi provinsi dengan taraf APM SMP yang telah sejajar dengan rata-rata nasional pada tahun 2015 s.d 2018.
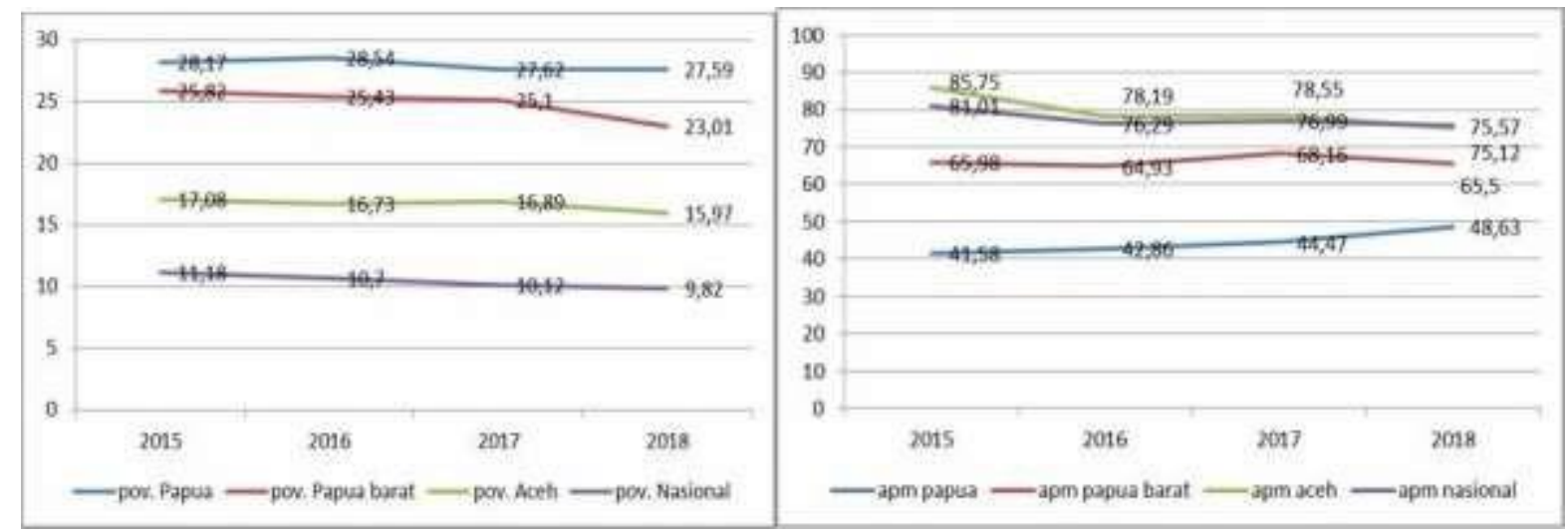

Grafik 4.5. Perbandingan Angka Kemiskinan dan Angka Partisipasi Murni (APM) SMP di Papua, Papua Barat, dan Aceh

*) Sumber : Pengolahan Data BPS \& Kemdikbud

Tabel di bawah memperlihatkan bahwa Aceh telah memiliki APM tertinggi pada seluruh jenjang pendidikan dibanding Papua dan Papua Barat. Bahkan APM Aceh secara umum telah berhasil melebihi rata-rata nasional pada 2015 sd 2018. Kondisi berbeda terjadi di Papua yang memiliki APM jauh di bawah rata-rata nasional dan berada di bawah Aceh dan Papua Barat pada seluruh jenjang pendidikan. Jenjang pendidikan dengan angka partisipasi sekolah tertinggi adalah pada tingkat Sekolah Dasar/ sederajat baik pada provinsi Aceh, Papua, Papua Barat maupun secara nasional. Persentase partisipasi akan semakin menurun seiring dengan semakin tinggi tingkat pendidikan. Gejala ini terlihat pada provinsi Aceh, Papua, Papua Barat maupun nasional 


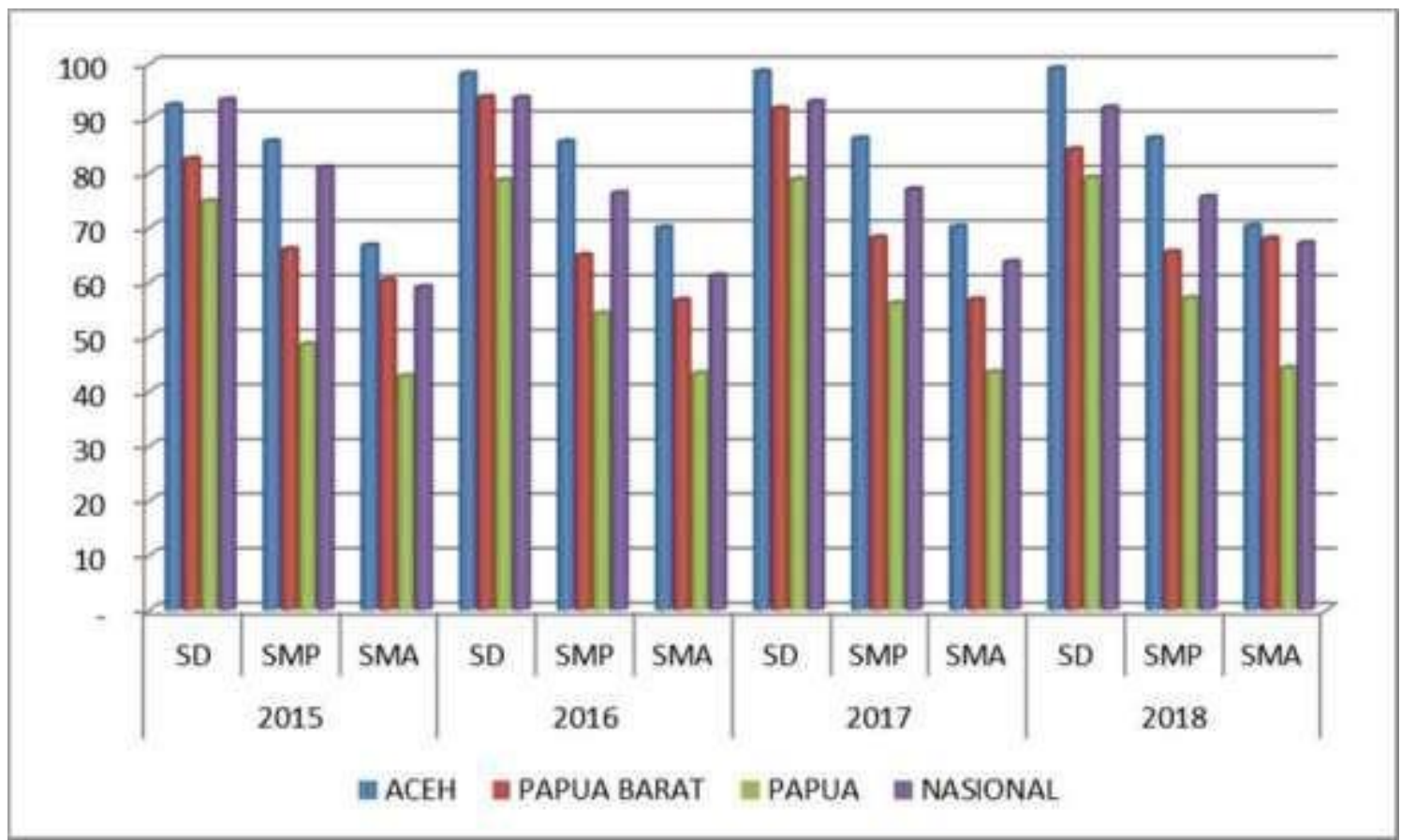

\section{Grafik 1. Angka Partisipasi Murni Pada Berbagai Jenjang Pendidikan di Aceh, Papua, Papua Barat, dan Indonesia}

*Sumber : web APM Kemdikbud, diolah

Penurunan angka APM yang cukup curam terjadi pada tingkat SD ke SMP pada seluruh jenjang pendidikan. Ini memperlihatkan bahwa terdapat jauh lebih sedikit penduduk usia sekolah SMP/ sederajat yang menempuh pendidikan pada jenjang tersebut karena berbagai alasan termasuk diantaranya tidak melanjutkan sekolah di jenjang SMP/sederajat atau harus menempuh pendidikan jenjang SD/sederajat secara lebih lama dari yang seharusnya. Skema Distribusi Dana Otonomi Khusus Dana Otonomi Khusus selanjutnya menjadi salah satu sumber penerimaan dalam APBD Aceh tiap tahun. Tata cara pengalokasian Dana ini selanjutnya diatur dalam Qanun Aceh yang ditetapkan oleh Gubernur tiap tahun. Dana Otsus pertama diperuntukkan untuk membiayai program bersama pemerintah provinsi dan pemerintah kabupaten/kota dengan perincian a) minimal $50 \%$ bagi pembangunan infrastruktur dan b) minimal $5 \%$ untuk pelaksanaan syariah Islam. Setelah dikurangi dengan kedua pembiayaan tersebut, maka Dana Otonomi Khusus akan dialokasikan sebesar $60 \%$ bagi pemerintah provinsi dan $40 \%$ bagi pemerintah kabupaten/kota. Formula pembagian di tingkat pemerintah kabupaten kota adalah a) $50 \%$ dialokasikan dengan proporsi sama besar, dan b) $50 \%$ sisanya menggunakan indikator sebagai berikut ; jumlah penduduk (40\%), luas wilayah (30\%), IPM (20\%), dan Indeks Kemahalan Konstruksi (10\%). 


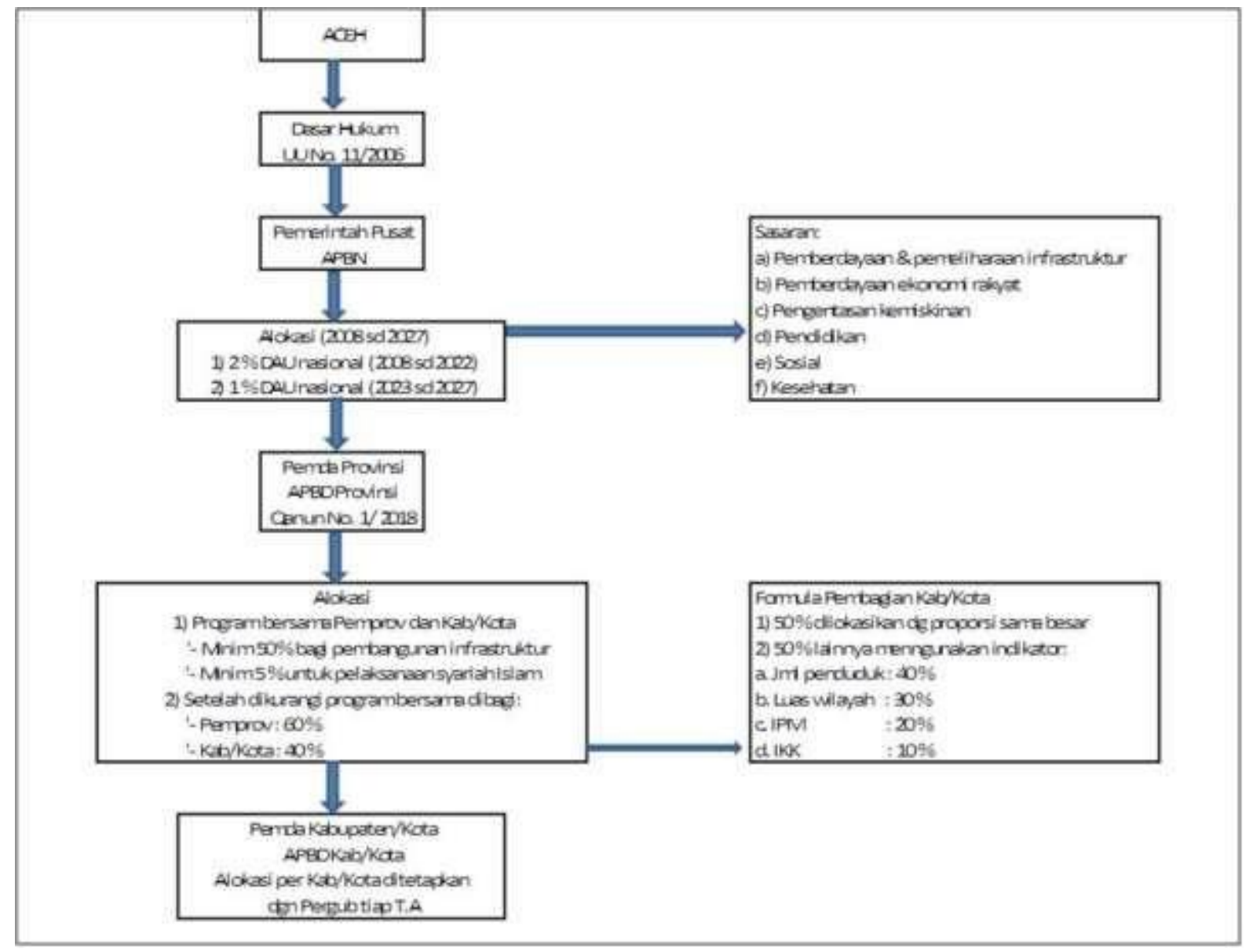

\section{Gambar 2. Skema Distribusi Dana Otsus Aceh}

Sumber : Qanun Aceh No.1/2018

Sementara itu, alokasi dana Otonomi Khusus bagi Papua menurut pasal 36 UU No. 21 Tahun 2001 Jo UU No. 35/ 2008 tentang Otonomi Khusus bagi Provinsi Papua dan Papua Barat adalah minimum $30 \%$ bagi sektor pendidikan dan minimum $15 \%$ bagi sektor kesehatan dan perbaikan gizi. Menurut Undang Undang ini, transfer Dana Otsus bagi Papua dan Papua Barat hanya berlangsung selama 20 tahun . Hal ini berarti, Papua dan Papua Barat tidak akan menerima lagi Dana Otsus masing-masing pada tahun 2022 mendatang. Pembagian besaran Dana Otsus untuk kedua provinsi paling timur ini ialah $70 \%$ bagi Papua dan $30 \%$ bagi Papua Barat dari total $2 \%$ DAU nasional.

Dana Otonomi Khusus selanjutnya menjadi salah satu sumber penerimaan dalam APBD Papua tiap tahun. Pembagian penerimaan dan pengelolaan Dana Otonomi Khusus selanjutnya diatur dalam Peraturan Daerah Khusus yang ditetapkan Gubernur tiap tahun. Sasaran pembiayaan Dana Otsus meliputi pendidikan (minimal $30 \%$ ), kesehatan (minimal 15 $\%$ ), pengembangan ekonomi kerakyatan (minimal $25 \%$ ), infrastruktur (minimal $20 \%$ ), lembaga keagamaan dan adat (maksimal $6 \%$ ), perencanaan \& monev ( maksimal $2 \%$ ), dan lainnya (maksimal $2 \%$ ). Dana Otsus pertama diperuntukkan untuk membiayai program strategis bersama pemerintah provinsi dan pemerintah kabupaten/kota. Setelah dikurangi dengan kedua pembiayaan tersebut, maka Dana Otonomi Khusus akan dialokasikan sebesar $20 \%$ bagi pemerintah provinsi dan $80 \%$ bagi pemerintah kabupaten/kota. Formula pembagian di tingkat pemerintah kabupaten kota adalah a) $50 \%$ dialokasikan dengan 
proporsi sama besar, dan b) $50 \%$ sisanya menggunakan indikator sebagai berikut ; jumlah penduduk (40 \%), luas wilayah (30\%), IPM (20\%), dan Indeks Kemahalan Konstruksi (10 $\%)$.

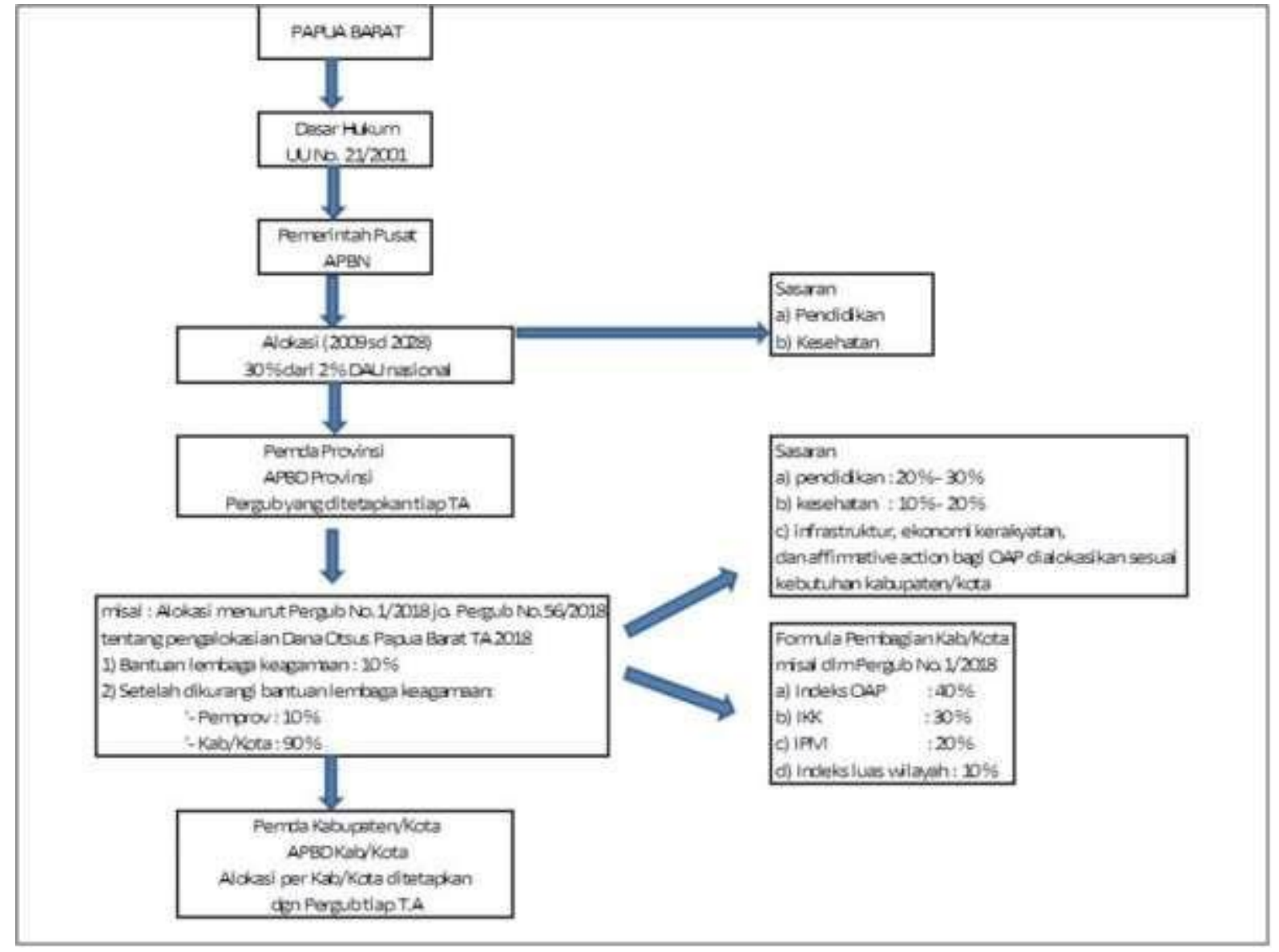

\section{Gambar 4. Skema Distribusi Dana Otsus Papua Barat}

Sumber : Pergub Papua Barat No.1/2018 jo. No.56/2018

Dana otonomi khusus menurut UU No. 12 Tahun 2018 tentang Anggaran Pendapatan dan Belanja Negara Tahun 2019 merupakan dana yang bersumber dari APBN untuk membiayai pelaksanaan otonomi khusus suatu daerah yang telah ditetapkan melalui UndangUndang sebagai daerah khusus atau istimewa. Otonomi khusus Aceh, Papua dan Papua Barat dilatarbelakangi oleh pengelolaan dan pemanfaatan hasil kekayaan alam yang masih belum didayagunakan secara optimal untuk peningkatan taraf dan kualitas hidup masyarakat setempat. Otonomi Khusus merupakan kebijakan khusus pemerintah pusat untukmengurangi kesenjangan pembangunan dengan daerah lain di wilayah NKRI. Kebijakan ini akan memberikan kewenangan yang lebih besar bagi pemerintah daerah untuk mengatur dan mengelola sendiri pemerintahannya dalam kerangka NKRI.

\section{Analisis Hasil Estimasi Model}

Tabel di bawah ini memperlihatkan bahwa penerimaan yang bersumber dari Dana Otsus hanya mampu mempengaruhi secara signifikan atas Angka Kemiskinan dan Angka Partsisipasi Murni jenjang SMP pada kabupaten/kota di Papua Barat pada tahun 2013-2018. Setiap peningkatan 1\% Dana Otsus akan mampu menurunkan Angka Kemiskinan sebesar $2.838 \%$ dan meningkatkan Angka Partisipasi Murni jenjang SMP sebesar 6.329 \%. Hasil ini sesuai dengan penelitian (Monika, 2018) dan (Hartati et al., 2016). 
Tabel 3. Hasil Analisis Inferensial Kabupaten/Kotadi Aceh, Papua, dan Papua Barat

\begin{tabular}{|c|c|c|c|}
\hline VARIABEL/LOKUS & ACEH & PAPUA & $\begin{array}{l}\text { PAPUA } \\
\text { BARAT }\end{array}$ \\
\hline \multicolumn{4}{|c|}{ ANGKA KEMISKINAN } \\
\hline Dana Otsus & $\begin{array}{c}0.149 \\
(0.132)\end{array}$ & $\begin{array}{c}0.474 \\
(0.337)\end{array}$ & $\begin{array}{c}-2.838^{* *} \\
(0.618)\end{array}$ \\
\hline Pendapatan Asli Daerah & $\begin{array}{c}-0.591 * * \\
(0.191)\end{array}$ & $\begin{array}{c}0.150 \\
(0.081)\end{array}$ & $\begin{array}{c}0.137 \\
(0.250)\end{array}$ \\
\hline Dana Perimbangan & $\begin{array}{c}0.826 \\
(0.789)\end{array}$ & $\begin{array}{c}0.045 \\
(0.188)\end{array}$ & $\begin{array}{l}-0.574 \\
(0.535)\end{array}$ \\
\hline $\begin{array}{l}\text { Realisasi Belanja } \\
\text { Perlindungan Sosial }\end{array}$ & $\begin{array}{l}-0.018 \\
(0.126) \\
\end{array}$ & $\begin{array}{c}0.082 \\
(0.160)\end{array}$ & $\begin{array}{l}-0.464 \\
(0.312)\end{array}$ \\
\hline $\begin{array}{l}\text { Produk Domestik } \\
\text { Regional Bruto per } \\
\text { Kapita }\end{array}$ & $\begin{array}{l}-3.040 * * \\
(1.111)\end{array}$ & $\begin{array}{l}-6.023 * * \\
(1.089)\end{array}$ & $\begin{array}{c}0.408 \\
(2.097)\end{array}$ \\
\hline Populasi & $\begin{array}{l}-6.448 * * \\
(1.812)\end{array}$ & $\begin{array}{l}-2.652 \\
(1.705)\end{array}$ & $\begin{array}{c}-12.549 * * \\
(2.919)\end{array}$ \\
\hline \multicolumn{4}{|c|}{$\begin{array}{l}\text { ANGKA PARTISIPASI } \\
\text { MURNI }\end{array}$} \\
\hline Dana Otsus & $\begin{array}{c}0.135 \\
(1.021)\end{array}$ & $\begin{array}{c}1.201 \\
(3.451)\end{array}$ & $\begin{array}{l}6.329 * * \\
(3.103)\end{array}$ \\
\hline Pendapatan Asli Daerah & $\begin{array}{c}0.630 \\
(1.465)\end{array}$ & $\begin{array}{c}0.918 \\
(0.787)\end{array}$ & $\begin{array}{c}2.097 \\
(1.467)\end{array}$ \\
\hline Dana Perimbangan & $\begin{array}{r}-11.631 \\
(6.042)\end{array}$ & $\begin{array}{c}0.041 \\
(1.836)\end{array}$ & $\begin{array}{l}-5.031 \\
(3.088)\end{array}$ \\
\hline $\begin{array}{l}\text { Realisasi Belanja } \\
\text { Pendidikan }\end{array}$ & $\begin{array}{l}-0.993 \\
(0.552)\end{array}$ & $\begin{array}{l}-0.458 \\
(1.870)\end{array}$ & $\begin{array}{l}-0.231 \\
(1.311)\end{array}$ \\
\hline $\begin{array}{l}\text { Produk Domestik } \\
\text { Regional Bruto per } \\
\text { Kapita }\end{array}$ & $\begin{array}{c}- \\
36.690 \\
* * \\
(8.357)\end{array}$ & $\begin{array}{c}7.242 \\
(22.34 \\
1)\end{array}$ & $\begin{array}{l}-4.571 \\
(3.293)\end{array}$ \\
\hline Populasi & $\begin{array}{c}-50.499 * * \\
(13.892)\end{array}$ & $\begin{array}{c}121.693 * * \\
(48.517)\end{array}$ & $\begin{array}{c}12.575 * * \\
(3.947)\end{array}$ \\
\hline
\end{tabular}

Sumber : hasil pengolahan data

Secara umum faktor-faktor yang terkonfirmasi berpengaruh signifikan terhadap Angka Kemiskinan dalam studi ini adalah Dana Otsus (di Papua Barat), Pendapatan Asli Daerah (di Aceh), Produk Domestik Regional Bruto per Kapita (di Aceh, Papua), serta populasi (di Aceh, Papua Barat). Sedangkan faktor faktor yang berpengaruh signifikan terhadap partisipasi pendidikan jenjang SMP ialah Dana Otsus (di Papua Barat), Produk Domestik Regional Bruto per Kapita (di Aceh), dan populasi (di Aceh, Papua, Papua Barat Sementara itu penerimaan daerah yang berasal dari Dana Otonomi Khusus tidak berpengaruh signifikan terhadap Angka kemiskinan kabupaten/kota di Aceh, dan Papua,. Hal ini kemungkinan disebabkan oleh beberapa faktor seperti aspek regulasi, maupun penggunaan anggaran. Dari aspek regulasi tidak ditemukan persentase alokasi yang eksplisit bagi pengentasan kemiskinan di level Undang-Undang maupun Qanun (di Aceh), dan Undang-Undang (di Papua). Oleh karena ketiadaan kejelasan regulasi, penggunaan Dana Otsus di Aceh untuk pengentasan kemiskinan hanya mencapai 2-3 \%. Demikian juga yang terjadi di Papua dan Papua Barat, penggunaan Dana Otsus bagi pengentasan kemiskinan 
hanya dimasukkan ke dalam sektor lainnya, sehingga tidak spesifik dan kurang transparan. Selain itu penggunaan Dana Otsus di Papua relatif digunakan untuk program yang kurang berkualitas dan tidak berdampak jangka panjang. Dana Otonomi Khusus juga tidak berpengaruh signifikan terhadap partisipasi pendidikan jenjang SMP di Papua dan Aceh. Hal ini dapat dilihat melalui aspek penggunaan anggaran maupun aspek regulasi. Penggunaan Dana Otsus sektor pendidikan di Papua tahun 2014-2018 masih di bawah $30 \%$ dari ketentuan seharusnya menurut UU dan Perdasus yakni minimum $30 \%$. Permasalahan non fiskal lainnya terkait partisipasi pendidikan di Papua adalah tingkat kesadaran, kondisi geografis dan pemukiman yang tersebar serta jauh dari layanan pendidikan. Sementara itu, penggunaan Dana Otsus sektor pendidikan di Aceh masih terfokus pada pembangunan fisik pendidikan semata. Secara regulasi pun, tidak terdapat persentase alokasi sektor pendidikan yang eksplisit pada Undang-Undang atau Qanun Aceh yang mengatur Otonomi Khusus.

Tabel 4. Tabulasi Dana Otsus, Angka Kemiskinan dan

Angka Partisipasi Murni SMP Kabupaten/Kota di Aceh, Papua, dan Papua Barat

\begin{tabular}{|c|c|c|c|c|c|c|}
\hline \multirow{2}{*}{ 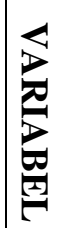 } & \multicolumn{3}{|c|}{ Poverty } & \multicolumn{3}{|c|}{ APM } \\
\hline & Aceh & Papua & $\begin{array}{l}\text { Papua } \\
\text { Barat }\end{array}$ & Aceh & Papua & $\begin{array}{l}\text { Papua } \\
\text { Barat }\end{array}$ \\
\hline & $\begin{array}{l}\text { - Tidak } \\
\text { signifi } \\
\text { kan }\end{array}$ & - Tidak & - Signifikan & - Tidak & - Tidak & $\begin{array}{l}\text { - Signifik } \\
\text { an }\end{array}$ \\
\hline 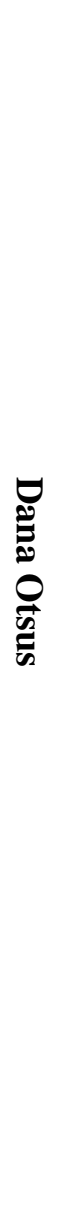 & $\begin{array}{l}\text { - Aspek } \\
\text { Pengguna } \\
\text { an } \\
\text { Anggaran: } \\
\text { Pengguna } \\
\text { an dana } \\
\text { hanya 2\%- } \\
3 \% \\
(2014- \\
2016) \\
\text { - Aspe } \\
\text { k } \\
\text { Regul } \\
\text { asi: } \\
\text { Tidak } \\
\text { terdapat } \\
\text { persentase } \\
\text { alokasi } \\
\text { secara } \\
\text { ekspilist di } \\
\text { UU } \\
\text { \& Qanun }\end{array}$ & $\begin{array}{l}\text { - Asp } \\
\text { ek } \\
\text { Peng } \\
\text { guna } \\
\text { an } \\
\text { Ang } \\
\text { gara } \\
\text { n : } \\
\text { a. Penggun } \\
\text { aan dana } \\
\text { untuk } \\
\text { kegiatan } \\
\text { kecil, } \\
\text { berdurasi } \\
\text { pendek, } \\
\text { b. Sektor } \\
\text { ini dalam } \\
\text { realisasi } \\
\text { penggun } \\
\text { aan dana } \\
\text { masuk } \\
\text { ke dalam } \\
\text { sektor } \\
\text { lainnya } \\
\text { Sehingga } \\
\text { tidak } \\
\text { spesifik }\end{array}$ & $\begin{array}{l}\text { - Aspek } \\
\text { Pengguna } \\
\text { an } \\
\text { Anggaran } \\
\vdots \text { Sektor } \\
\text { ini dalam } \\
\text { realisasi } \\
\text { penggunaa } \\
\text { n dana } \\
\text { masuk ke } \\
\text { dalam } \\
\text { sektor } \\
\text { lainnya } \\
\text { sehinggati } \\
\text { dak } \\
\text { spesifik. } \\
\text { - Aspek } \\
\text { Regulasi: } \\
\text { Tidak } \\
\text { terdapat } \\
\text { persentase } \\
\text { alokasi } \\
\text { secara } \\
\text { eksplisit } \\
\text { di UU } \\
\text { maupun }\end{array}$ & $\begin{array}{l}\text { - Aspek } \\
\text { Pengg } \\
\text { unaan } \\
\text { Angg } \\
\text { aran : } \\
\text { a. Rata-rata } \\
\text { penggunaa } \\
\text { n dana } \\
\text { sektor } \\
\text { pendidikan } \\
\text { mencapai } \\
20.9 \% \\
\text { (2012- } \\
\text { 2016) } \\
\text { b. Terlalu } \\
\text { fokus pada } \\
\text { pembangu } \\
\text { nan fisik, } \\
\text { belum } \\
\text { pada } \\
\text { aspek } \\
\text { peningkat } \\
\text { an } \\
\text { partisipasi } \\
\text { pendidika } \\
\text { n. } \\
\text { - Aspek }\end{array}$ & \begin{tabular}{l} 
- Aspek \\
Penggunan \\
Anggaran: \\
Penggunaan \\
dana otsus \\
sektor pendi \\
- \\
dikan masih \\
di bawah \\
\multicolumn{1}{c}{$30 \%$} \\
(2014-2018). \\
Ketentuan \\
regulasi (UU \\
\& Perdasus) \\
minimal 30 \\
\%. \\
- Aspek \\
Sosial \\
Geografis \\
Permasalahan \\
partisipasi \\
pendidikan di \\
Papua \\
adalah tingkat \\
kesadaran, \\
kondisi \\
geografis dan \\
pemukiman
\end{tabular} & $\begin{array}{l}\text { - Aspek } \\
\text { Penggu } \\
\text { naan } \\
\text { Anggar } \\
\text { an: } \\
\text { Penggu } \\
\text { naan } \\
\text { danotsu } \\
\text { s sektor } \\
\text { pendi - } \\
\text { dikan(2 } \\
014- \\
2018) \\
\text { sudah } \\
\text { sesuai } \\
\text { dengan } \\
\text { Pergub } \\
\text { sebesar } \\
20 \% \\
\text { s.d. } 30 \\
\% \text {. }\end{array}$ \\
\hline
\end{tabular}




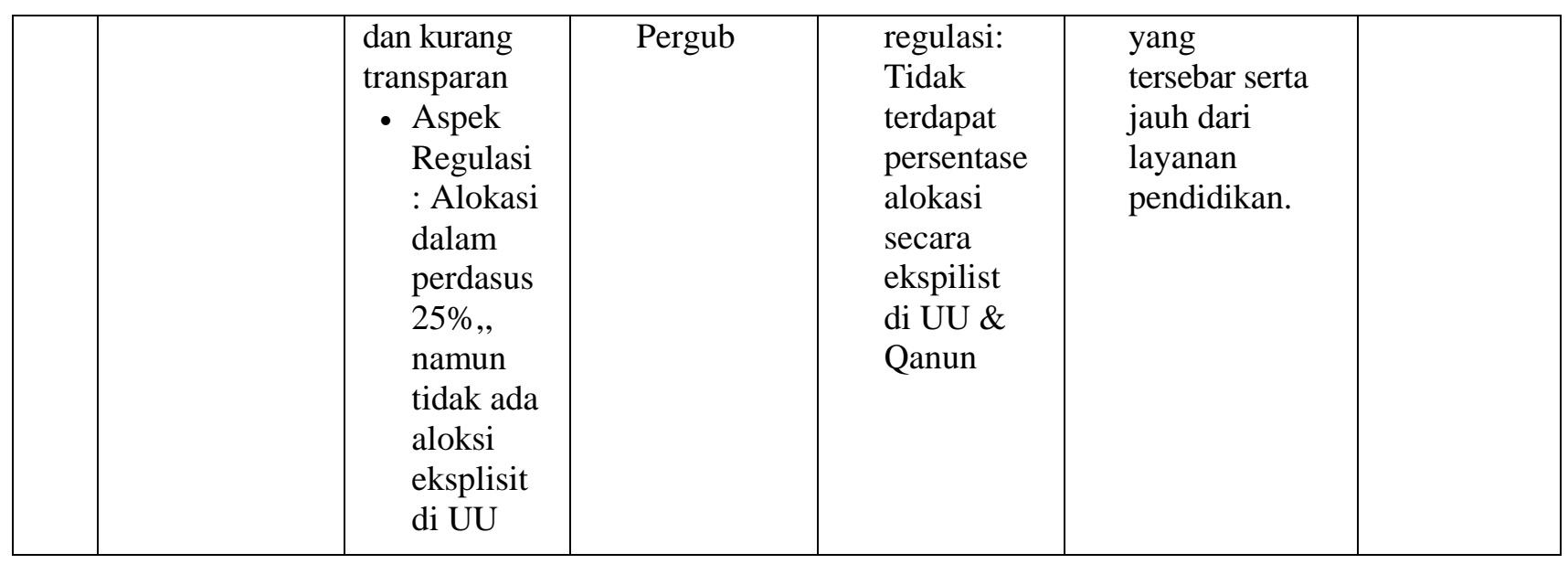

*Sumber : Kajian Literatur

\section{Kesimpulan}

Angka kemiskinan di kabupaten/kota di Papua Barat tahun 2013-2018 terbukti sinifikan turut dipengaruhi oleh penerimaan Dana Otsus. Peningkatan Dana Otsus sebesar 1\% dapat menurunkan Angka Kemiskinan sebesar $2.838 \%$. Sementara itu penerimaan daerah yang berasal dari Dana Otonomi Khusus tidak berpengaruh signifikan terhadap Angka kemiskinan kabupaten/kota di Aceh, dan Papua. Hal ini kemungkinan disebabkan oleh beberapa faktor seperti aspek regulasi, maupun penggunaannya. Dari aspek regulasi tidak ditemukan persentase alokasi yang eksplisit bagi pengentasan kemiskinan di level Undang- Undang maupun Qanun (di Aceh), dan Undang-Undang (di Papua). Oleh karena ketiadaan kejelasan regulasi, penggunaan Dana Otsus di Aceh untuk pengentasan kemiskinan hanya mencapai 2- $3 \%$. Demikian juga yang terjadi di Papua, penggunaan Dana Otsus relatif digunakan untuk program yang kurang berkualitas dan tidak berdampak jangka panjang. Selain itu penggunaan Dana Otsus bagi pengentasan kemiskinan juga hanya dimasukkan ke dalam sektor lainnya, sehinga tidak spesifik dan kurang transparan.

Dana Otonomi Khusus menunjukkan pengaruh yang siginifikan pada partisipasi pendidikan jenjang SMP kabupaten/kota di Papua Barat. Setiap peningkatan Dana Otsus sebesar $1 \%$ akan turut meningkatan partisipasi pendidikan jenjang SMP kabupaten/kota di Papua Barat sebesar 6.329 \%. Penggunaan Dana Otsus bagi sektor pendidikan di Papua Barat pada tahun 2014-2018 telah sesuai dengan minimum alokasi yang diatur dalam Peraturan Gubernur sebagai aturan pelaksana yakni sebesar 20 - $30 \%$. Namun, Dana Otonomi Khusus tidak berpengaruh signifikan terhadap partisipasi pendidikan jenjang SMP kabupaten/kota di Papua dan Aceh. Hal ini dapat dilihat melalui aspek penggunaan anggaran maupun aspek regulasi. Penggunaan Dana Otsus sektor pendidikan di Papua tahun 2014-2018 masih dibawah $30 \%$ dari ketentuan seharusnya menurut UU dan Perdasus yakni minimum $30 \%$. Sementara itu, penggunaan Dana Otsus sektor pendidikan di Aceh masih terfokus pada pembangunan fisik pendidikan semata. Secara regulasi pun, tidak terdapat persentase alokasi sektor pendidikan yang eksplisit pada Undang- Undang atau Qanun Aceh yang mengatur Otonomi Khusus. 


\section{Bibliografi}

Agustina, C. D., Ahmad, E., Nugroho, D., \& Siagian, H. (2012). Political economy of natural resource revenue sharing in Indonesia.

Astuti, I. A. P., \& Astika, I. B. P. (2016). Pengaruh Jumlah Penduduk, Dana Alokasi Umum, Dan Dana Alokasi Khusus Terhadap Kesejahteraan Masyarakat Kabupaten/Kota Di Provinsi Bali. E-Jurnal Akuntansi, 17(3), 2416-2446.

Dardias, B. (2012). Model lmplementasi Desentralisasi Asimetris yang Menyejahterakan: Belajar dari Pengalaman Aceh dan Papua. Yogyakarta: Belum Diterbitkan.

Hartati, C. S., Abdullah, S., \& Saputra, M. (2016). Pengaruh penerimaan dana otonomikhusus dan tambahan dana bagi hasil migas terhadap belanja modal serta dampaknya pada indeks pembangunan manusia Kabupaten/Kota di Aceh. Jurnal Administrasi Akuntansi: Program Pascasarjana Unsyiah, 5(2).

Monika. (2018). Dampak Dana Otonomi Khusus Terhadap Kemiskinan di Provinsi Papua Periode 2010-2016. IPB.

Rasu, K. J. E., Kumenaung, A. G., \& Koleangan, R. A. M. (2019). ANALISIS PENGARUH DANA ALOKASI KHUSUS, PENDAPATAN ASLI DAERAH, DANA ALOKASI UMUM DAN DANA BAGI HASIL TERHADAP TINGKAT KEMISKINANDI KOTA MANADO. JURNAL PEMBANGUNAN EKONOMI DAN KEUANGAN DAERAH, 20(2), $1-14$.

Tauda, G. A. (2018). Desain Desentralisasi Asimetris Dalam Sistem Ketatanegaraan Republik Indonesia. Administrative Law \& Governance Journal, 1(4), 413-435. 